\title{
An improved selective medium for the isolation of Escherichia coli 0157
}

\author{
P. A. CHAPMAN, CHRISTINE A. SIDDONS, P. M. ZADIK and LINDA JEWES
}

Public Health Laboratory, Northern General Hospital, Herries Road, Sheffield S5 7AU

\begin{abstract}
Summary. Sorbitol-MacConkey medium has become widely used for the isolation of verotoxigenic $\left(\mathrm{VT}^{+}\right)$Escherichia coli $\mathrm{O} 157$. However, many organisms other than $\mathrm{VT}^{+}$ E. coli O157, especially other serogroups of E. coli and Proteus spp., may not ferment sorbitol, and thus may be confused initially with $\mathrm{VT}^{+} E$. coli O157. Rhamnose is not fermented by $\mathrm{VT}^{+}$E. coli O157, but is by most sorbitol non-fermenting $E$. coli of other serogroups. Cefixime is a cephalosporin antibiotic that is more active against Proteus spp. than against $E$.coli. Inclusion of rhamnose and cefixime in sorbitol-MacConkey agar improves its selectivity for the isolation of $\mathrm{VT}^{+} E$. coli $\mathrm{O} 157$.
\end{abstract}

\section{Introduction}

Strains of Escherichia coli that produce a potent cytotoxin active against cultured Vero cells are now recognised as important pathogens of man. ${ }^{1}$ These verotoxigenic $E$. coli (VTEC) have been associated with outbreaks and sporadic cases of haemorrhagic colitis (HC) in North America ${ }^{2,3}$ and in England, ${ }^{4,5}$ and with sporadic cases of haemolytic-uraemic syndrome (HUS) in Canada ${ }^{6,7}$ and in England. ${ }^{5,8}$ Both HC and HUS have been associated with high morbidity and mortality. ${ }^{9}$

Beef products and untreated milk have both been suggested as possible sources of VTEC for man. ${ }^{2,10}$ Verotoxin-producing $\left(\mathrm{VT}^{+}\right)$E. coli $\mathrm{O} 157$, the most common serogroup of VTEC isolated from man, has been isolated from cattle, ${ }^{5}$ although the route of transmission from cattle to man was not established. ${ }^{11}$ Person-to-person transmission of $\mathrm{VT}^{+}$E. coli $\mathrm{O} 157$ has also been documented. ${ }^{12,13}$

Strains of $\mathrm{VT}^{+} E$. coli do not ferment sorbitol, and sorbitol-MacConkey (SMAC) medium has been described for their selective culture. ${ }^{14}$ This medium is now widely used in clinical diagnostic laboratories. However, some $E$. coli strains of serogroups other than $\mathrm{O} 157$ are also sorbitol non-fermenters (NSF), as are members of several other genera found frequently in faecal samples, especially Proteus spp.

All $\mathrm{VT}^{+}$E. coli $\mathrm{O} 157$ isolated hitherto in the Sheffield area, and strains of $\mathrm{VT}^{+} E$. coli $\mathrm{O} 157$ sent to us from elsewhere, have given identical results on biochemical testing. ${ }^{5,11}$ All isolates failed to ferment sorbitol, inositol, adonitol, rhamnose, cellobiose, sorbose and salicin. Biochemical tests on organisms isolated on SMAC from human and animal faeces

Received 24 Nov. 1990; accepted 29 Nov. 1990. during $1987-1990$, showed that $60 \%$ of NSF E. coli of serogroups other than 0157 fermented rhamnose (Sheffield PHL - unpublished data). About $15 \%$ of NSF organisms isolated were Proteus spp. Cefixime is a cephalosporin antibiotic that is more active against Proteus spp. than against $E$. coli. ${ }^{15}$

The aim of this study was to determine whether inclusion of rhamnose and cefixime would improve SMAC medium for the isolation of $\mathrm{VT}^{+} E$. coli $\mathrm{O} 157$.

\section{Materials and methods}

\section{Cefixime MICs}

Cefixime powder was a gift from Cyanamid (Gosport, Hants) and was prepared initially as a solution of $4 \mathrm{~g} / \mathrm{L}$ in ethanol, as advised by the manufacturers. Doubling dilutions of cefixime, range, $4-0.002 \mathrm{mg} / \mathrm{L}$, were prepared in $100-\mu$ l volumes in sterile microtitration plates (Sterilin), with MacConkey Broth (Oxoid, CM5a) with glucose $1 \%$ as diluent. Isolates to be tested were grown in nutrient broth at $37^{\circ} \mathrm{C}$ for $3 \mathrm{~h}$ and these cultures were diluted 1 in 100 in diluent as above to prepare an inoculum of $c .10^{5}$ organisms $/ \mathrm{ml} ; 100 \mu l$ of inoculum were added to each dilution of cefixime; after mixing, the plates were incubated at $37^{\circ} \mathrm{C}$ overnight. The lowest dilution of cefixime that inhibited growth (no turbidity or colour change) was recorded as the MIC. MICs were determined for 98 strains of $\mathrm{VT}^{+}$E. coli $\mathrm{O} 157$ and 22 strains of Proteus spp. previously isolated from faecal samples.

\section{Rhamnose fermentation}

SMAC Medium (Oxoid, CM813) was prepared with added rhamnose, in a series of concentrations, 
$0 \cdot 1-1 \%$ in $0 \cdot 1 \%$ steps. Control organisms $\left(\mathrm{VT}^{+} E\right.$. coli O157 sorbitol-negative and rhamnose-negative, and $E$. coli $\mathrm{O} 26$ sorbitol-negative and rhamnose-positive) were grown on each plate to determine the lowest concentration of rhamnose that produced an easily observed colour change when fermented.

\section{Cefixime-rhamnose-sorbitol-MacConkey (CR- $S M A C)$ medium}

SMAC medium was prepared with added cefixime $0.05 \mathrm{mg} / \mathrm{L}$ and rhamnose $0.5 \%$. The medium was tested in parallel with SMAC for ability to support the growth of: $\mathrm{VT}^{+} E$. coli $\mathrm{O} 157$ isolated in Sheffield (84 strains), $\mathrm{VT}^{+}$E. coli $\mathrm{O} 157$ from diverse locations within the UK (96), Proteus spp. (34), NSF E. coli of serogroups other than $\mathrm{O} 157$ (27), Morganella morganii (16), Providencia spp. (15) and E. hermanii (2). The test strains were inoculated on to each medium and the plates were incubated at $37^{\circ} \mathrm{C}$ overnight. Growth and rhamnose fermentation were recorded. $\mathrm{VT}^{+} E$. coli 0157 strains were checked for latex-test reactivity from CR-SMAC by a previously described method. ${ }^{16}$

\section{Comparison of SMAC and CR-SMAC in routine diagnostic tests}

Selection of patients. Patients studied were those with acute diarrhoea of unknown aetiology. Faecal samples were sent from General Practices, the Communicable Diseases Unit of Lodge Moor Hospital, Sheffield, and other hospitals in the Sheffield area. All samples submitted during August and September 1990 were examined.

Examination of faecal samples. Samples were inoculated on to SMAC and CR-SMAC media and the plates were incubated at $37^{\circ} \mathrm{C}$ overnight. Each colonial type of non-fermenter was identified by a series of biochemical tests ${ }^{5}$ and a latex test ${ }^{16}$ for $E$. coli $\mathrm{O} 157$. If faecal samples were from patients with bloody diarrhoea, HC or HUS, and, therefore, more likely to contain $\mathrm{VT}^{+} E$. coli $\mathrm{O} 157,{ }^{5}$ six non-fermenting colonies were examined from each medium.

\section{Results}

\section{Cefixime MICs}

Cefixime MICs for $\mathrm{VT}^{+}$E. coli $\mathrm{O} 157$ were in the range $0.125-0.5 \mathrm{mg} / \mathrm{L}$, and for Proteus spp. 0.004$0.016 \mathrm{mg} / \mathrm{L}$. Table I shows further details of MIC results.

\section{Rhamnose fermentation}

An easily observed colour change as a result of fermentation was obtained only with rhamnose concentrations above $0.4 \%$.
Table I. Cefixime MICs for $\mathrm{VT}^{+}$E. coli $\mathrm{O} 157$ and Proteus spp.

\begin{tabular}{|c|c|c|}
\hline \multirow{2}{*}{$\begin{array}{c}\mathrm{MIC} \\
(\mathrm{mg} / \mathrm{L})\end{array}$} & \multicolumn{2}{|c|}{ Number of strains of } \\
\hline & $\begin{array}{c}\mathrm{VT}^{+} \text {E. coli } \mathrm{O} 157 \\
(\mathrm{n}=98)\end{array}$ & Proteus spp. $(\mathrm{n}=22)$ \\
\hline 0.5 & 12 & - \\
\hline $0 \cdot 25$ & 76 & - \\
\hline $0 \cdot 125$ & 10 & 一 \\
\hline 0.06 & - & 一 \\
\hline 0.03 & 一 & - \\
\hline 0.016 & - & 9 \\
\hline 0.008 & - & 10 \\
\hline 0.004 & - & 3 \\
\hline
\end{tabular}

\section{Growth on CR-SMAC}

All $\mathrm{VT}^{+}$E. coli $\mathrm{O} 157$ test strains grew on CRSMAC as non-fermenting colonies, and all gave positive latex test results. All strains of Proteus spp. were inhibited by CR-SMAC. Of 27 strains of NSF $E$. coli of serogroups other than $\mathrm{O} 157,25$ grew on CRSMAC and of these 23 fermented rhamnose. Fourteen of $16 \mathrm{M}$. morganii strains grew on the medium, as did 11 of 15 strains of Providencia spp; however of these 11,10 were of much reduced colony size when compared with growth on SMAC medium. Both strains of $E$. hermanii grew on CR-SMAC and fermented rhamnose.

\section{Comparison of CR-SMAC and SMAC in routine diagnostic tests}

During the study period, 1763 samples were inoculated on to both media. $\mathrm{VT}^{+} E$. coli $\mathrm{O} 157$ was isolated from seven samples; six of these isolates grew equally well on both media, but in one instance, five of six NSF colonies from SMAC were Hafnia spp. and only one was $\mathrm{VT}^{+}$E. coli O157, whereas non-fermenting colonies from CR-SMAC medium were all $\mathrm{VT}^{+} E$. coli O157. From SMAC medium, 411 non-fermenting colony types were investigated from 397 samples: of these, 169 were NSF E. coli of serogroups other than O157, 46 were Proteus spp. and 196 were other NSF genera. From CR-SMAC medium, 178 non-fermenting colony types were investigated from 176 samples; of these 44 were NSF $E$. coli of serogroups other than O157, nine were Proteus spp. and 125 were other NSF genera. Thus $397(22.5 \%)$ samples required further investigations of growth from SMAC medium, and with 14 of these samples investigation of more than one NSF colony type was required. From CR-SMAC, growth from $176(10 \%)$ of samples required further investigation, and with two of these samples investigation of more than one colony type was required. Table II shows the results of the comparison in full. 
Table II. Comparison of SMAC and CR-SMAC medium for primary isolation of $\mathrm{VT}^{+}$E. coli $\mathrm{O} 157$

\begin{tabular}{l|rr}
\hline \multirow{2}{*}{$\begin{array}{c}\text { NSF organism } \\
\text { isolated }\end{array}$} & \multicolumn{2}{c}{ Number of isolates obtained on } \\
\cline { 2 - 3 } & \multicolumn{1}{c}{ SMAC } & CR-SMAC \\
\hline VT ${ }^{+}$E. coli O157 & $7(0 \cdot 4)^{*}$ & $7(0 \cdot 4)$ \\
Other NF E. coli & $169(9 \cdot 6)$ & $44(2 \cdot 5)$ \\
Proteus spp. & $46(2 \cdot 6)$ & $9(0 \cdot 5)$ \\
M. morganii & $33(1 \cdot 9)$ & $37(2 \cdot 1)$ \\
Hafnia spp. & $28(1 \cdot 6)$ & $15(0 \cdot 9)$ \\
Providencia spp. & $20(1 \cdot 1)$ & $4(0 \cdot 2)$ \\
Enterobacter spp. & $13(0 \cdot 7)$ & $13(0 \cdot 7)$ \\
Pseudomonas spp. & $12(0 \cdot 7)$ & $12(0 \cdot 7)$ \\
Aeromonas spp. & $7(0 \cdot 4)$ & $7(0 \cdot 4)$ \\
Others & $69(3 \cdot 9)$ & $37(2 \cdot 1)$ \\
Total & $411(23 \cdot 3)$ & $178(10 \cdot 1)$ \\
\hline
\end{tabular}

*Numbers in parenthesis are the percentages of samples from which the organism was isolated.

\section{Discussion}

HC and HUS are serious infections affecting patients of all ages and of either sex. ${ }^{1}$ Indeed, HUS, which is more common in young children, is now the single commonest cause of renal failure in children in North America and in England and Wales. ${ }^{17}$ VTEC strains are now recognised as important causal agents of both these conditions. ${ }^{2-7}$ Unfortunately, in most cases, the source of these infections has not been elucidated, and the epidemiology of the infections remains unclear. The use of simpler methods for the isolation and identification of $\mathrm{VT}^{+} E$. coli $\mathrm{O} 157$ would facilitate further epidemiological studies.

It has been reported that $\mathrm{VT}^{+}$E. coli $\mathrm{O} 157$ strains do not ferment sorbitol, unlike most other $E$. coli. ${ }^{3,18}$ Therefore, SMAC medium has become widely used for the isolation of $\mathrm{VT}^{+}$E. coli O157.4, 5,12,19, 20 However, reports of its selectivity for $\mathrm{VT}^{+}$E. coli O157 differ widely. Using SMAC, Smith et al.$^{4}$ isolated $\mathrm{VT}^{+}$E. coli $\mathrm{O} 157$ from $22 \%$ of samples examined, whereas Walker $e t$ al $^{20}$ isolated these organisms from only $0.5 \%$; this disparity is likely to reflect differences between highly selected samples sent to a reference laboratory and the routine examination of acute samples in a service laboratory. In their examination of faecal samples, several workers ${ }^{5,20}$ have found NSF organisms other than E. coli O157 to be commoner than earlier reports from North America suggested. Walker et al. ${ }^{20}$ found NSF organisms in $16 \%$ of faecal samples, most of which were NSF E. coli and Proteus spp. We have reported similar findings. ${ }^{5}$ In the present study, the results in table II show that in the examination of 1763 faecal samples, 411 organisms required further investigation from primary cultures on SMAC, whereas only 178 did so from CR-
SMAC medium. We believe that this would offer a significant saving of time and cost for a busy diagnostic laboratory. Seven isolates of $\mathrm{VT}^{+}$E. coli $\mathrm{O} 157 \mathrm{grew}$ on both media. However, in one instance, when six non-fermenting colonies were examined from each medium, only one colony from SMAC was of $\mathrm{VT}^{+}$ E. coli O157, whereas all colonies from CR-SMAC were $\mathrm{VT}^{+}$E. coli $\mathrm{O} 157$; in this case the organism could have easily been missed on SMAC medium. E. hermanii is a NSF organism which is isolated commonly from foodstuffs, and which may cross react antigenically with $E$. coli $\mathrm{O} 157$, causing false-positive results. ${ }^{21,22}$ Although in the current study only two isolates of $E$. hermanii were examined both fermented rhamnose and, therefore, would be distinguished easily from $\mathrm{VT}^{+} E$. coli $\mathrm{O} 157$ on CR-SMAC medium.

There are several alternatives to traditional techniques for the isolation and identification of $\mathrm{VT}^{+}$ E. coli $\mathrm{O} 157$. Genes coding for verotoxins 1 and 2 have been cloned and sequenced, ${ }^{23-26}$ and DNA probes produced from either labelled cloned fragments or synthetic oligonucleotides, have been described for detection of VTEC, including VT ${ }^{+}$E. coli $\mathrm{O} 157 .{ }^{27,28}$ However, despite the sensitivity and specificity of these techniques, they are likely to be too expensive for, and beyond the scope of, most routine diagnostic laboratories. Serological confirmation of infection by detecting antibodies against purified LPS from $\mathrm{VT}^{+}$ E. coli $\mathrm{O} 157$ has been described, ${ }^{29,}{ }^{30}$ but this test is one used only by reference laboratories. Detection of free faecal verotoxin by cell culture assay has been used with success as a diagnostic method, ${ }^{4,5}$ but specific antitoxin is needed for confirmation of a positive result; this test is not yet available commercially.

In contrast to alternative methods, selective culture is simple, quick and inexpensive and isolates may be readily and reliably identified with a commercially available latex test kit. ${ }^{16}$ Isolation of the organism also allows typing by techniques such as phage typing ${ }^{31}$ and plasmid analysis, the latter technique having been shown to provide useful epidemiological information. ${ }^{11}$

CR-SMAC performs better than SMAC for isolation of $\mathrm{VT}^{+}$E. coli $\mathrm{O} 157$, but further evaluation is needed. Development of better selective media, and in particular enrichment culture, would facilitate further studies on the prevalence of this organism and the epidemiology of its infections.

We thank Trent Regional Health Authority and Unipath Ltd for financial support for this work; the following colleagues for sending us isolates of $\mathrm{VT}^{+}$E. coli O157: Dr P. Cowling, Bristol; Dr P. Crichton-Gomes, Dundee; Dr B. A. S. Dale, Dumfries; Dr I. Farrell, Birmingham; Dr P. Hawkey, Leeds; Dr T. M. S. Reid, Aberdeen; and, Dr B. Rowe, London; and Cyanamid for supplying cefixime for this study.

\section{References}

1. Karmali MA. Infection by verocytotoxin-producing Escherichia coli. Clin Microbiol Rev 1989; 2: 15-38.
2. Riley LW, Remis RS, Helgerson SD et al. Hemorrhagic colitis associated with a rare Escherichia coli serotype. $N$ Engl $J$ Med 1983; 308: 681-685.

3. Pai $\mathbf{C H}$, Gordon R, Sims HV, Bryan LE. Sporadic cases of 
hemorrhagic colitis associated with Escherichia col O157:H7. Ann Intern Med 1984; 101 : 738-742.

4. Smith HR, Rowe B, Gross RJ, Fry NK, Scotland SM Haemorrhagic colitis and verocytotoxin-producing Escherichia coli in England and Wales. Lancet 1987; 1 : 10621065

5. Chapman PA, Wright DJ, Norman P. Verotoxin-producing Escherichia coli infections in Sheffield: cattle as a possible source. Epidemiol Infect $1989 ; 102$ : 439-445.

6. Karmali MA, Steele BT, Petric M, Lim C. Sporadic cases of haemolytic-uraemic syndrome associated with faecal cytotoxin and cytotoxin-producing Escherichia coli in stools. Lancet $1983 ; 1: 619-620$.

7. Karmali MA, Petric M, Lim C, Fleming PC, Arbus GS, Lior $H$. The association between idiopathic hemolyticuremic syndrome and infection by verotoxin-producing Escherichia coli. J Infect Dis 1985; 151: 775-782.

8. Scotland SM, Rowe B, Smith HR, Willshaw GA, Gross RJ. Vero cytotoxin-producing strains of Escherichia coli from children with haemolytic-uraemic syndrome and their detection by specific DNA probes. $J$ Med Microbiol 1988 25: 237-243.

9. Spika JS, Parsons JE, Nordenberg D, Wells JG, Gunn RA, Blake PA. Hemolytic uremic syndrome and diarrhea associated with Escherichia coli $\mathrm{O} 157: \mathrm{H} 7$ in a day care center. J Pediatr 1986; 109: 287-291.

10. Martin ML, Shipman LD, Wells JG et al. Isolation of Escherichia coli $\mathrm{O} 157: \mathrm{H} 7$ from dairy cattle associated with two cases of haemolytic-uraemic syndrome. Lancet 1986 2: 1043 .

11. Chapman PA, Jewes L, Siddons CA, Norman P, George SL. Verotoxin-producing Escherichia coli infections in Sheffield during 1989. PHLS Microbiol Digest 1990: 7: 163-166.

12. Ratnam S, March SB, Sprague WD, Severs D, Sullivan RM. Are humans a source of Escherichia coli $\mathrm{O} 157: \mathrm{H} 7$, the agent of hemorrhagic colitis? N Engl J Med 1986; 315 $1612-1613$

13. Carter AO, Borczyk AA, Carlson JA et al. A severe outbreak of Escherichia coli O157:H7 associated hemorrhagic colitis in a nursing home. $N$ Engl $J$ Med $1987 ; 317$ : 1496-1500.

14. March SB, Ratnam S. Sorbitol-MacConkey medium for detection of Escherichia coli $0157: \mathrm{H} 7$ associated with hemorrhagic colitis. J Clin Microbiol 1986; 23 : 869-872.

15. Wise R, Andrews JM, Ashby JP, Thornber D. In vitro activity of Bay $v$ 3522, a new cephalosporin, compared with activities of other agents. Antimicrob Agents Chemother $1990 ; 34: 813-818$.

16. Chapman PA. Evaluation of a commercial latex slide test for identifying Escherichia coli O157. J Clin Pathol 1989; 42: 1109-1110.

17. Report. Third Annual Report (1988-1989) of the British Paediatric Surveillance Unit, 1989.
18. Wells JG, Davis BR, Wachsmuth IK et al. Laboratory investigation of hemorrhagic colitis outbreaks associated with a rare Escherichia coli serotype. J Clin Microbiol 1983; 18: $512-520$.

19. Kleanthous H, Fry NK, Smith HR, Gross RJ, Rowe B. The use of sorbitol-MacConkey agar in conjunction with a specific antiserum for the detection of Vero cytotoxin-producing strains of Escherichia coli O157. Epidemiol Infect 1988; 101 327-335.

20. Walker CW, Upson R, Warren RE. Haemorrhagic colitis : detection of verotoxin producing Escherichia coli $\mathrm{O} 157$ in a clinical microbiology laboratory. J Clin Pathol 1988; 41 : 80-84.

21. Lior H, Borczyk AA. False positive identifications of Escherichia coli O157. Lancet 1987; 1: 333.

22. Borczyk AA, Lior H, Ciebin B. False positive identifications of Escherichia coli $\mathrm{O} 157$ in foods. Int J Food Microbiol 1987; 4: 347-349.

23. Willshaw GA, Smith HR, Scotland SM, Rowe B. Cloning of genes determining the production of vero cytotoxin by Escherichia coli. J Gen Microbiol 1985; 131 : 3047-3053.

24. Calderwood SB, Auclair F, Donohue-Rolfe A, Keusch GT Mekalanos JJ. Nucleotide sequence of the Shiga-like toxin genes of Escherichia coli. Proc Natl Acad Sci USA 1987; 84 4364-4368.

25. Jackson MP, Neill RJ, O'Brien AD, Homes RK, Newland JW Nucleotide sequence analysis and comparison of the structural genes for Shiga-like toxin I and Shiga-like toxin II encoded by bacteriophages from Escherichia coli 933 . FEMS Microbiol Lett $1987 ; 44$ : 109-114.

26. Strockbine NA, Jackson MP, Sung LM, Holmes RK, O'Brien $\mathrm{AD}$. Cloning and sequencing of the genes for Shiga toxin from Shigella dysenteriae type 1. J Bacteriol 1988; 170 : 1116-1122.

27. Willshaw GA, Smith HR, Scotland SM, Field AM, Rowe B Heterogeneity of Escherichia coli phages encoding vero cytotoxins: comparison of cloned sequences determing VT1 and VT2 and development of specific gene probes. $J$ Gen Microbiol 1987; 133: 1309-1317.

28. Karch H, Meyer T. Evaluation of oligonucleotide probes for identification of Shiga-like-toxin-producing Escherichia coli. J Clin Microbiol 1989; 27: 1180-1186.

29. Chart H, Scotland SM, Rowe B. Serum antibodies to Escherichia coli serotype $0157: \mathrm{H} 7$ in patients with hemolytic uremic syndrome. J Clin Microbiol 1989; 27 : 285-290.

30. Chart H, Scotland SM, Smith HR, Rowe B. Antibodies to Escherichia coli $\mathrm{O} 157$ in patients with haemorrhagic colitis and haemolytic-uraemic syndrome. J Clin Pathol 1989; 42 : 973-976.

31. Ahmed R, Bopp C, Borczyk A, Kasatiya S. Phage-typing scheme for Escherichia coli O157:H7. J Infect Dis 1987; 155: 806-809. 